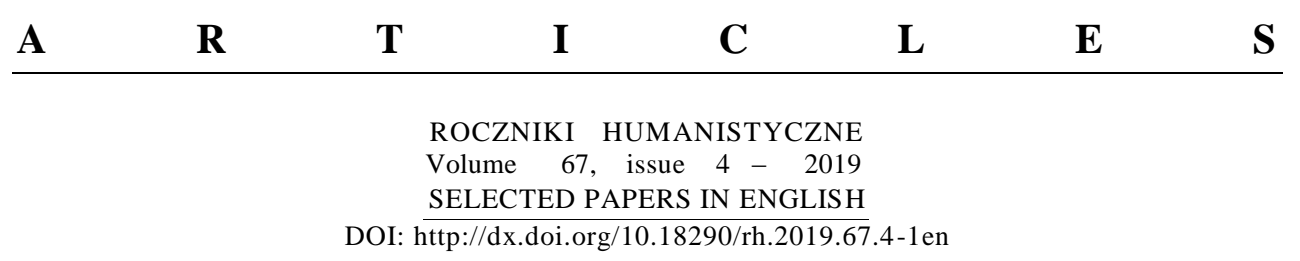

JANINA DZIK

\title{
THE RECEPTION OF THE ENGRAVINGS OF GOTTFRIED BERNHARD GÖZ'S MARIAN SERIES IN THE MONUMENTAL PAINTING OF THE LVIV CIRCLE IN THE $18^{\mathrm{TH}}$ CENTURY
}

A characteristic feature of the Rococo monumental painting in the Polish-Lithuanian Commonwealth of the Saxon era was the iconographic and compositional inspiration with the graphics of the Augsburg engravers. ${ }^{1}$ A major inspiring role was attributed to a series of Marian engravings by the Augsburg painter, draftsman and graphic artist Gottfried Bernhard Göz (born in Velehrad in 1708, died in Augsburg in 1774). Engravings named Sub tuum praesidium confugimus, he was mentioned by Erich Guldan in his iconographic study Eva und Maria (1966), following the suggestions of Norbert Lieb from Munich, who had discovered this rare series. ${ }^{2}$ It was the first time when the scientific literature had mentioned twelve engravings dated around the mid- $18^{\text {th }}$ century and stored in the Grafische Sammlung Stadtische Kunstsammlungen und Museen in Augsburg. Also, Gertrud Schiller in her Iconographie der christlichen Kunst (1980) spoke of the pivotal role of Göz's engravings in German monumental painting of the Rococo period as an

\footnotetext{
Dr JANINA DZIK—art historian, Kraków; e-mail: nina.dzik@gmail.com

The Polish version of the article was published in Roczniki Humanistyczne vol. 63, issue 4

${ }^{1}$ Janina DzIK, "Grafika dewocyjna braci Klauberów i jej recepcja w monumentalnym malarstwie polskim XVIII w.," Rocznik Biblioteki Naukowej PAN i PAU w Krakowie 54 (2009): 469-480.

${ }^{2}$ Erich Guldan, Eva und Maria (Graz-Köln: Gundolf, 1966), 69, 236; Stephan BeISSEL, Geschichte der Verehrung Marias im. 16. und 17. Jahrhundert (Freiburg i. Br.: Herdersche Verlagsbuchhandlung, 1910), 261; Paul EICH, "Empfängnis Mariae, unbefleckte," in Reallexikon zur Deutschen Kunstgeschichte, vol. V (München: C.H. Beck, 1967), 257.
} (2015). 
inspiration for iconographic programs and compositions on Marian themes, including, for example, the polychromes in Sankt Maria Parish Church in Niederaschau (Oberbayern, Germany), ${ }^{3}$ in the castle chapel in Neu-Celje (Slovenia) ${ }^{4}$ and at Santa Maria in Piedigrotta in Naples (Italy). ${ }^{5}$ Some individual engravings were discussed by Rudolf Wildmoser in a monograph work devoted to the legacy of Gottfried Bernhard Göz. ${ }^{6}$

The discussed series, ranked among numerous devotional series in graphic editing, consists of the title page and twelve signed scenes showing original Marian representations of emblematic nature. They are entitled Immaculate Conception of the Blessed Virgin Mary (Conceptio), Birth of the Virgin Mary (Nativitas), Presentation of the Virgin Mary (Praesentatio), Mary and Joseph's Matrimony (Desponsatio), Annunciation of the Blessed Virgin Mary (Annuntiatio), Visitation (Visitatio), Mary's Purification (Purificatio), the images of Our Lady of Sorrows (Passio), Assumption of Mary (Assumptio). Further scenes are associated with Mary's patronage as the Queen of the Rosary (Regina SS. Rosary) and Our Lady of the Scapular (Regina SS. Scapulieris), and finally with her intercession (Patrocinium). The representations, with a biblical commentary appended, refer to the events of Mary's life and her mediation which are commemorated by the Marian feasts in the ecclesiastical calendar. This is an example of small-size, copperplate engraving (87 $\mathrm{x} 133 \mathrm{~mm}$ ) made using the original - and experimental at that time-stipple technique and containing the signatures: C.P.S(aes). M (ai) and G.B. Göz at the bottom. A distinguishing characteristic of the series is the use of the stipple technique and the development of a composition with a packed group of figures against a flat, neutral background and without putting them into some spectacular architectural frame. The motif of slender figures wearing ordinary, pleated costumes is outlined with subtle delicacy and finesse as if in amorphous Rococo ornaments. Unique is also the decorativeness and fragmentariness of the architectural components that form the background and highlight an appropriate prop. These engravings prove, as the researchers of Göz's

\footnotetext{
${ }^{3}$ Gertrud SCHILLER, Ikonographie der christlichen Kunst, vol. IV, 2 (Gütersloh: Verlagshaus Gerd Mohn, 1980), 176, fig. 774.

${ }^{4}$ Roman TOMINIEC, "Immaculata in arte slovenica," in Virgo Immaculata. Acta Congressus mariologici-mariani Romae anno 1954 celebrati, vol. XV (Rome: Academia Mariana Internationalis, 1957), 151, footnote 53; Erich Guldan, Eva und Maria, 69, 236.

${ }^{5}$ Gennaro A. Galante, Guida sacra della citta di Napoli (Napoli: Stamperia del Fibreno, 1872), 396; Erich Guldan, Eva und Maria, 69, 236.

${ }^{6}$ Rudolf WiLDMOSER, Gottfried Bernhard Göz als ausführender Kupferstecher: Untersuchung und Katalog der Werke (Augsburg: Augsburger Buchdruck und Verlagswesen, 1984-85), 210-213.
} 
output stress, his mature style shaped in the years 1737-1740 when he established a publishing "company" with his brothers Joseph Sebastian and Johann Baptist Klauber. The company was granted the imperial privilege on 15 January 1742 (renewed in 1755 and 1766). From the 1840s, he became independent in creating his graphic compositions. The production of stipple engravings, often coloured and lacking ornamental frames, was secured by the imperial privilege and gained great recognition. Preferring the stipple copperplate technique and developing "freye Manier ohne viereggigte Rähm oder Fassung des Bildes," just like his contemporaries William W. Ryland and Francesco Bartolozzi, Göz sought to achieve extremely gentle effects of moulding. ${ }^{7}$ The compositions of Hendrik Goltzius and Antoine Watteau proved to be a true inspiration. In recognition of his merits, in 1744, he was awarded the honorary title of imperial painter and engraver by Emperor Charles VII. Shortly afterwards, he was accorded another privilege from Empress Maria Theresa (Goldenen Gnadenpfennig). ${ }^{8}$

Several symbol-rich representations from the Marian series mentioned above deserve special attention. Scene one, Conceptio, shows frontally posing Mary of the Immaculata type. She stands on a ball, holding a lily in her left hand and cloaking kneeling Adam and Eve, the first parents. The scene implies the role of Mary as the new Eve for whom, as Guldan put it, an important attribute is the protective cloak alluding to the power of a queen, Pallium Regina Misericordiae. ${ }^{9}$ Above her, a shining triangle is visible in the clouds with inside Baby Jesus descending in brightness. The background reveals branches covered in leaves: probably a reference to the Tree of Knowledge of Good and Evil (Fig. 1). ${ }^{10}$ The inscription, Dominus possedit me in initio. Prov. $8, v .22$, as G. Schiller claims, testified to the identification of Mary with the concept of the Old Testament Sapientia and to her choice by God to fulfil the pre-eternal salvation plan. ${ }^{11}$

In scene two, Nativitas, with the inscription, Dominare nostri Tu, et Filus tuus. Iudic. 8.v. 22, the main figure is seated St Anne, holding her baby daughter

\footnotetext{
${ }^{7}$ Krzysztof KRUŻel, Jan MotYKA, Francesco Bartolozzi. Ryciny ze zbiorów graficznych Polskiej Akademii Nauk w Krakowie (Kraków: Międzynarodowe Centrum Kultury, 1995), 16.

${ }^{8}$ Eduard IsPHORDING, "Göz Gottfried Bernhard," in Allgemeines Künstler-Lexikon, vol. 57, (München: Saur, 2008), 141-142; Gerhard WOECKEL, "Göz Gottfrired Bernhard," in Neue Deutsche Biographie, vol. VI (Berlin: Duncker \& Humblot, 1964), 586.

${ }^{9}$ Guldan, Eva und Maria, 236; EICH, "Empfangnis,” 257.

${ }^{10}$ Guldan, Eva und Maria, 236.

${ }^{11}$ SCHILLER, Ikonographie, 176.
} 
Mary. The visible Marian monogram supported on a crescent with a winding snake on an oval cartouche placed on the cradle is a symbolic designation of the Immaculate Conception. Above, there are some symbolic signs of a Trinitarian character: the Holy Spirit as a dove and an anchor-a symbol of hope, the Eye of Providence and the figure of a child - the Son of God descending towards Mary in rays (Fig. 2). ${ }^{12}$ The composition symbolically depicts the idea of God's plan of salvation and the selection of Mary as the Mother of the Son of God.

In scene three, Praesentatio, signed, Placuit oblatio, Gen. 24.v. 18, St Anne leads Mary to the Jerusalem temple to present her to the high priest, thus fulfilling the vow made after the birth of the long-awaited child. ${ }^{13}$ The dainty-looking girl walks up the steps towards the priest who wears a characteristic headgear and extends his welcoming arms. On the right, in the foreground, there is kneeling Joachim, closing the composition on the other side. A piece of local architecture and the tablets with the Ten Commandments and a slender candlestick suggest that they are inside a monumental building (Fig. 3).

In the middle of scene four, Desponsatio, with the inscription, Mulieris Bonae Beatus Vir. Eccli.26.v. 1, we can see the figures of the betrothed before the priest in the iconographic tradition of dextrarum iunctio. Joseph holding a blossoming wig puts a ring on Mary's finger, her head crowned with a wreath. The high priest stands on an elevation between them. In the background a seven-branched candlestick and the tablets with the Ten Commandments (Fig. 4). ${ }^{14}$

In scene five, Annuntiatio, we can see the representation of the Incarnation; this event is not only vital for Mary's life, but it is a breakthrough moment in history and the climax of God's plan of salvation. The engraving shows interaction between two figures: an angel with a lily in winnowed clothes descending from heaven and Mary on the kneeler during prayer. Above them, there is the Holy Spirit as a dove and descending Baby Jesus in the rays of light (Fig. 5). ${ }^{15}$

In scene twelve, Patrocinium, Mary asks for mercy for the sinful world, Pete Mater mea: neque enim fas est, ut avertam faciem tuam, 3.Reg.2.v 20. ${ }^{16}$ The S-shaped composition exhibits the figures of Christ and Mary aloft

\footnotetext{
${ }^{12}$ WILDMOSER, Gottfried Bernhard Göz, 210-213.

${ }^{13}$ Ibidem.

${ }^{14}$ Ibidem.

${ }^{15}$ Ibidem.

${ }^{16}$ Guldan, Eva und Maria, 236.
} 
in clouds; Mary apparently turns to her son asking for protection over the Church (?), personified by a female figure leaning against the globe. Mary is depicted from the left side, in winnowed, draped clothes, with a nimbus of stars around her head, facing frontally posed Christ holding a rod in his right hand. Next to him, a skull with a crossed bone and sword symbolizing punishment and destruction (Fig. 6). ${ }^{17}$

In his painting works, Gottfried B. Göz repeated the iconographic motifs discussed above. The scene of the Virgin Mary's intercession to Christ known from Patrocinium appeared in an oval painting of 1748 on the vault of the nave of St Stephen's Church of the Dominican nuns in Habsthal (Upper Swabia) featuring St Dominic as an intercessor standing by an altar and appealing to the Mother of God facing Christ (Fig. 7). ${ }^{18}$ Patrocinium was repeated in Göz's and his decoration of the chancel of the Cistercian church in Bimau (1748 -1750). The depicting of Intercessio Mariae (1748-1750), in a rich Marian programme of the interior, was a typological reference to the main scene below portraying Esther before Ahasuerus begging for her nation (Fig. 8). ${ }^{19}$

The graphic series was used as a model for murals decorating Bavarian Marian shrines, such as Frauenchiemsee, Maria Mitleid Kapelle and Mater Dolorosa Kapelle, with Balthasar Furtner's paintings (1761). The latter was inspired by Göz's engravings in the representations of the Immaculate Conception, Visitation, and Mary's birth. ${ }^{20}$ Mary as Reparatrix Mundi, Advocata nostra, part of the aforesaid series, can be found in a church in Niederaschau. ${ }^{21}$ To decorate his main work-paintings on the vault of the pilgrimage church in Klein Mariazell (1763-1765), the Austrian painter Johann Baptist Wenzel Bergl (1718-1789), a student of Paul Troger (Fig. 9), also relied on the series as a model. ${ }^{22}$

References to Göz's series can also be traced in Slovenia. The Slovenian painter Anton Jožef Lerhinger (Lerchinger) used the Conceptio formula for

\footnotetext{
${ }^{17}$ WILDMOSER, Gottfried Bernhard Göz, 210-213.

${ }^{18}$ Eduard IsPHORDING, Gottfried Bernhard Göz, 1708-1774. Ein Augsburger Historienmaler des Rokoko und seine Fresken (Weissenhorn: Konrad, 1997), 38-40, figs. 10, 16; WOECKEL, "Göz Gottfrired," 586.

${ }^{19}$ IsPHORDING, Gottfried Bernhard Göz, 1997, figs. 15, 16.

${ }^{20}$ Hermann BAUER, Frank BütTNER, Bernhard RuPPRECht, ed., Corpus der barocken Deckenmalerei in Deutschland-Bayern: Landkreis Rosenheim, vol. 12/ I (München: Süddeutscher Verlag: 2007), 156-160.

${ }^{21}$ Ibidem, vol. 12/ II; SCHILLER, Ikonographie, 176.

${ }^{22}$ IsPhORding, "Göz Gottfrired Bernhard," 2008, 141-142; Wolfgang HaUG, John THIEDE, "Bergl Johann Baptist Wenzel," in Allgemeines Kunstler-Lexikon, vol. 57, 393.
} 
a scene with rich illusionist ornamentation on the vault of the Castle Chapel of St George (Grajska Kapela) in Novo Celje dated 1758-1763 (?) (Fig. 10). ${ }^{23}$

These graphic works, not covered by any earlier studies, were known among the Lviv artists of the $18^{\text {th }}$ century and served as a model for figural compositions in wall painting. The Lviv painter Stanisław Stroiński (1719 -1802) employed such engravings. His work can be seen in the Bernardine Marian shrine in Leżajsk, Poland, and in Holy Spirit Church operated by the same fraternity in Chervonohrad (Ukraine) ${ }^{24}$

Stanisław Stroiński, who continued his painting work on the aisle walls after the coronation of the miraculous painting, accompanied by Maciej and Mateusz Miller (1757-1758), used the discussed Marian series in panels above the south arcade. ${ }^{25}$ The figural scenes of Mary's Introduction to the Temple and Mary's Matrimony, borrowed from the engravings Praesentatio and Desponsatio, were incorporated into an elongated composition of panels with gentle illusionist architecture to create the impression of the interior of an extravagant building (Figs. 11, 12). The following year (1758), Stroiński completed a scene on the east wall of the north nave above the entrance to St Francis of Assisi Chapel. He signed it with the date 1758. The painting was Mary's intercession during the Wrath of the Lord, fairly popular across the churches of the Franciscan Order. He relied on the Patrocinium graphics showing Christ with mediating Mary and introduced the founders of mendicant orders, St Francis of Assisi and St Dominic (Fig. 13). ${ }^{26}$ At the same time, i.e. in the years 1756-1759, Stanisław Stroiński used the Nativitasengraving when decorating

\footnotetext{
${ }^{23}$ Anica CEvc, Anton Jožef Lerhinger (Lubljana: Ljubljana Narodna Galerija 2007), 124.

${ }^{24}$ Janina DzIK, "Idea gloryfikacji Marii w polichromii sklepienia kościoła bernardynów w Leżajsku," Biuletyn Historii Sztuki 71, book 3 (2009): 281-317; Janina DzIK, “Ikonografia polichromii pobernardyńskiego kościoła Ducha Świętego w Krystynopolu," in Homo creator et receptor artium. Ksiega pamiatkowa ks. prof Stanisławowi Kobielusowi ofiarowana, ed. Małgorzata Wrześniak (Warszawa: Wydawnictwo Uniwersytetu Kardynała Stefana Wyszyńskiego, 2010), 279-301.

${ }^{25}$ Zbigniew Hornung, "Stanisław Stroiński (1719-1802)," Prace Sekcji Historii Sztuki i Kultury Towarzystwa Naukowego we Lwowie 2, book 5 (1935): 54-59; Katalog zabytków sztuki w Polsce, vol. 3 (new series), "Województwo rzeszowskie," book 4, "Leżajsk, Sokołów Małopolski i okolice,” ed. Ewa Śnieżyńska-Stolotowa and Franciszek Stolot (Warszawa: Wydawnictwa Artystyczne i Filmowe, 1989, 40, fig. 159; DzIK, "Idea gloryfikacji," 40, 159.

${ }^{26}$ Ibidem, XI, 4, fig. 157. Janina DZIK, Euntes in mundum universum praedicate evangelium. Programy ideowe osiemnastowiecznych malowideł kościołów zakonnych na ziemiach południowowschodnich dawnej Rzeczypospolitej (Kraków: Księgarnia Akademicka, 2014), 61-90.
} 
the interior of the Bernardine church in Chervonohrad (Ukraine), specifically the vault of an extension adjacent to the aisle. ${ }^{27}$ The figural scene (now destroyed), faithfully transferred from the original, was incorporated into a monumental square composition in a longitudinal space delineated by a mock frame. The figures are shown on rising stairs (Fig. 14).

The same group of figures was faithfully repeated in one of the last works of the aged artist in the vault of St. Anne's Chapel of the Holy Trinity Church of Benedictine nuns in Zasań, Przemyśl, Poland, made during the reconstruction of the temple in the years $1773-1777 .^{28}$ The figures are shown against architectural elements against the sky and among clouds with visible symbols of the Holy Trinity. This scene was included in the chapel's iconographic programme dedicated to Mary's mother (Fig. 15).

Parallel with the painting of the Benedictine church, works were carried out on the interior decoration of St Mary Magdalene's Church in Przemyśl, Poland, operated by the Conventual Franciscans. According to historic records, the work lasted on-and-off from 1771 until 1778 when the church was consecrated (19 July). The author was Józef Rybkiewicz, the court painter of the Przemyśl bishop, Józef Tadeusz Kierski (part of the chancel, up to the first span of the west nave) and the Lviv artist Antoni Winiarski (probably the aisle and other vaults over the naves). They most probably relied on Stroinski's design. ${ }^{29}$ To produce the scene of the Annunciation of the Blessed Virgin Mary in the chancel vault, the painter used the Annuntiatio engraving as a model (Fig. 16). He thus referred to the older solution adopted by Stroiński in the chancel part of the church in Chervonohrad. ${ }^{30}$

Other artists were familiar with the Augsburg series as well. The representation of the Immaculate Conception of the Blessed Virgin Mary served as a model for the image of Mary in the polychrome of the vault of the chancel

\footnotetext{
${ }^{27}$ Hornung, "Stanisław Stroiński," 62-66; DzIK, "Ikonografia polichromii," 279-301.

${ }^{28}$ Katalog zabytków sztuki w Polsce, vol. 10 (new series), "Miasto Przemyśl," ed. Jakub Sito, part 1, "Zespoły sakralne," ed. Piotr Krasny i Jakub Sito (Warszawa: Instytut Sztuki PAN, 2004), 110-111, fig. 120.

${ }^{29}$ Hornung, "Stanisław Stroiński," 89-93; Józef FrazIK, "Budowniczowie i artyści na usługach franciszkanów przemyskich od XVI do XVIII wieku na tle dziejów kościoła i jego wyposażenia," Biuletyn Historii Sztuki 37 (1975): 312-334; Józef FrAZıK, "Budowniczowie i artyści na usługach franciszkanów przemyskich od XVIII wieku," in Sztuka Przemyśla i ziemi przemyskiej. Zbiór studiów, ed. Maria Dłutek, Jerzy Kowalczyk (Przemyśl-Warszawa: Instytut Sztuki Polskiej Akademii Nauk, 2004), 117-141.

${ }^{30}$ Zbigniew HoRnUng, Uwagi w sprawie autorstwa polichromii ściennej kościoła oo. Franciszkanów w Przemyślu, "Teka Konserwatorska. Polska południowo-wschodnia," vol. II (Rzeszów: Biuro Dokumentacji Zabytków w Rzeszowie, 1985), 213222, in part. 213-215.
} 
of St Lawrence Parish Church in the village of Żółkiewka, Poland (Fig. 17). ${ }^{31}$ The paintings were made by Gabriel Sławiński in 1776. They adorned the interior of the newly erected church funded by Tomasz Stamierowski, the Krasnostaw starost, and the owner of the village (Fig. 18). ${ }^{32}$ The scene with Our Lady the Immaculate and kneeling first parents Adam and Eve proved important for further studies. For the second time, it was made on the deep-beam wall of the aisle of the post-Pauline St Louis Church in Włodawa, Poland (Fig. 19). That recurrent use of this motif allowed Andrzej Stoga to observe that it was made by Gabriel Sławiński after 1784, probably after the sudden death of Antoni (Marcel) Dobrzyniewski (Dobrzeniecki, 1731-1780), Stroiński’s follower. ${ }^{33}$

The records discussed above testify to the influence of the Augsburg graphics, which led the way in the European editing of the time, on Polish $18^{\text {th }}$-century painting. The engravings were particularly inspiring as they represented innovative compositional solutions with regard to style, technique, and original approach to the conventional religious theme. The engravings of the Rococo masters, brothers Joseph Sebastian and Johann Baptist Klauber, Martin Engelbrecht, Johann Georg Bergmuller, were particularly valued. Their scenes and motifs borrowed by other artists were used in various religious contexts, especially by Stanisław Stroiński, who was probably inspired by them in the decoration of the parish church of Our Lady of the Snows in the years 1750-1751 (recorded as Annunciation, Visitation, Mary and Joseph's Matrimony). ${ }^{34}$ They were part of the Marian-rich iconographic programme. ${ }^{35}$

\footnotetext{
${ }^{31}$ Włodzimierz SMOSARSKI, Malowidła ścienne Gabriela Stawińskiego w kościele parafialnym pod wezwaniem św. Wawrzyńca w Żótkiewce (MA paper written under the supervision of Prof. Antoni Maśliński) (Lublin, 1968).

${ }^{32}$ Katalog zabytków sztuki w Polsce, vol. 8, "Woj. lubelskie," ed. Ryszard Brykowski and Ewa Rowińska, book 8, "Powiat krasnostawski" (Warszawa: Instytut Sztuki PAN, 1964), 79, fig. 73; see also, Andrzej STOGA, "Quadratura w malarstwie polskim XVIII w. Malowidła na sklepieniach," Biuletyn Historii Sztuki 42 (1980): 365-376; Magdalena SzYndLAREwICZ, "Gabriel Sławińskimalarz fresków i obrazów. Uwagi wstępne," in Między Wrocławiem a Lwowem. Sztuka na Ślasku, Małopolsce i na Rusi Koronnej w czasach nowożytnych, ed. Andrzej Betlej, Katarzyna Brzezina, Piotr Oszczanowski (Wrocław: Wydawnictwo Uniwersytetu Wrocławskiego, 2011), 349-358.

${ }^{33}$ Katalog zabytków sztuki w Polsce, vol. 8, "Woj. lubelskie," book 18, "Pow. włodawski," ed. Janina Rutkowska and Ewa Smulikowska (Warszawa: Instytut Sztuki PAN, 1975); Halina SoBIESZCZUK, "Malowidła ścienne w kościele popaulińskim we Włodawie," Roczniki Humanistyczne 6 (1957): 271-281; Andrzej STOGA, "Marceli Dobrzeniewski—zagadkowy malarz z Włodawy i Łęczeszyc," Biuletyn Historii Sztuki 34 (1972): 341-345.

${ }^{34}$ Felicjan ŁOBESKI, "Opisy obrazów znajdujących się w kościołach miasta Lwowa,” Dodatek Tygodniowy do Gazety Lwowskiej 2 (1852): 126-127; HoRnUNG, "Stanisław Stroiński," 51-52; Jan K. OstRowsKI, "Kościół parafialny p.w. Matki Boskiej Śnieżnej,” in Kościoły i klasztory rzymsko-katolickie dawnego województwa ruskiego. Materiały do dziejów sztuki sakralnej na ziemiach
} 
The series came to Poland probably around 1750 , so shortly after edition. This fact confirms regular contact of the Lviv artistic community with that of Augsburg. The graphic series in question is a specific example of "a wandering and repetitive motif" in the 18th-century painting of the Latin universum. It was especially popular, as exemplified, in interior decorations of Marian shrines.

Stanisław Stroiński, an extremely engaged painter of the Lviv circle, demonstrating the skill and dexterity of the brush and using effective quadrature solutions, knew the achievements of European wall painting, partly through his familiarity with the graphic patterns. ${ }^{36}$ That is why the hypotheses about the painter's Italian education do not hold. The same was true about the next generation of painters. The adaptation of foreign designs helped elevate the level of artistically impoverished country peripheries.

\section{LIST OF FIGURES}

1. Conceptio, engraving from the series, Life of Mary, ca. 1750, Gottfried Bernhard Göz, reprod.: E. Guldan, Eva und Maria, Graz-Köln 1966

2. Nativitas, engraving from the series, Life of Mary, ca. 1750, Gottfried Bernhard Göz, reprod.: Fotoarchiv, Grafische Sammlungen Stadt Augsburg, Kunstsammlungen und Museen, Augsburg

3. Presentatio, engraving from the series, Life of Mary, ca. 1750, Gottfried Bernhard Göz, reprod.: Wildmoser, Gottfried Bernhard Göz..., fig. 37

4. Patrocinium, engraving from the series, Life of Mary, ca. 1750, Gottfried Bernhard Göz, reprod.: Fotoarchiv, Grafische Sammlungen Stadt Augsburg, Kunstsammlungen und Museen, Augsburg

5. Annuntiatio, engraving from the series, Life of Mary, ca. 1750, Gottfried Bernhard Göz, reprod.: Fotoarchiv, Grafische Sammlungen Stadt Augsburg, Kunstsammlungen und Museen, Augsburg

6. Patrocinium, engraving from the series, Life of Mary, ca. 1750, Gottfried Bernhard Göz, reprod.: Fotoarchiv, Grafische Sammlungen Stadt Augsburg, Kunstsammlungen und Museen, Augsburg

7. Intercession of St Dominic, 1748, Gottfried Bernhard Göz, painting on the vault of the aisle of St Stephen' Church of Dominican nuns in Habsthal, Germany

8. Intercessio Mariae, 1748-1750, Gottfried Bernhard Göz, painting on the vault of the pilgrimage church in Birnau, Germany

9. Mary's Matrimony, 1763-1765, Johann Baptist Wenzel Bergl, painting on the vault of Kleinmariazell Church, Austria

wschodnich dawnej Rzeczypospolitej. Kościoly i klasztory Lwowa z okresu przedrozbiorowego, vol. XIX, part 1, ed. Jakub Adamski [et al.] (Kraków: Międzynarodowe Centrum Kultury w Krakowie, 2011), 38.

${ }^{35}$ OSTROWSKI, “Kościół,” 38.

${ }^{36}$ Joanna DARANOwSKA-ŁUKASZEwSKA, "Stroiński Stanisław," in Polski Stownik Biograficzny, vol. XLIV, 2006/2007, 342-344; HoRnUnG, "Stanisław Stroiński," 343. 
10. Immaculate Conception of the Blessed Virgin Mary, 1758-1763, Anton Jozef Lerhinger (Lerchinger), painting on the vault of Grajska Kapela in Novo Celje, Slovenia

11. Mary's Introduction to the Temple (fragment), 1757, Stanisław Stroiński, wall painting in the aisle of the Bernardine church in Leżajsk, Poland

12. Mary's Matrimony (fragment), 1757, Stanisław Stroiński, wall painting in the aisle of the Bernardine church in Leżajsk, Poland

13. Intercession during Lord's Wrath, 1758, Stanisław Stroinski, painting in the nave of the Bernardine church in Leżajsk, Poland

14. St Anne, 1758, Stanisław Stroiński, painting on the vault of the Bernardine church in Chervonohrad, Ukraine

15. Adoration of the Holy Trinity by St Anne with Baby Mary, 1773-1777, Stanisław Stroiński, painting on the vault of the Chapel of St Anne of the church of Benedictine nuns in Przemyśl, Poland

16. Annunciation of the Blessed Virgin Mary, 1771-1777, J. Rybkiewicz, painting on the vault of the chancel of the Conventual Franciscan church in Przemyśl, Poland

17. Immaculate Conception of the Blessed Virgin Mary, ca. 1776, Gabriel Sławiński, painting on the vault of the chancel of the parish church in Żółkiewka, Poland

18. Immaculate Conception of the Blessed Virgin Mary, after 1784, Gabriel Sławiński, painting in the aisle of the post-Pauline church in Włodawa, Poland

\section{BIBLIOGRAPHY}

Corpus der barocken Deckenmalerei in Deutschland-Bayern: Landkreis Rosenheim. Vol. 12/ I and II, ed. Hermann Bauer, Frank Büttner, Bernhart Rupprecht. München: Süddeutscher Verlag, 2007.

BeISSEL, Stephan. Geschichte der Verehrung Marias im. 16. und. 17. Jahrhundert. Freiburg i. Br.: Herdersche Verlagsbuchhandlung, 1910.

CEVC, Anton. Jožef Lerhinger. Lubljana: Ljubljana Narodna Galerija, 2007.

Daranowska-ŁukAsZewska, Joanna. “Stroiński Stanisław.” In Polski Słownik Biograficzny. Vol. XLIV, 2006/2007.

DzIK, Janina. "Grafika dewocyjna braci Klauberów i jej recepcja w monumentalnym malarstwie polskim XVIII w.” Rocznik Biblioteki Naukowej PAN i PAU w Krakowie 54 (2009).

DzIK, Janina. "Idea gloryfikacji Marii w polichromii sklepienia kościoła bernardynów w Leżajsku.” Biuletyn Historii Sztuki 71 (2009).

DZIK, Janina. "Ikonografia polichromii pobernardyńskiego kościoła Ducha Świętego w Krystynopolu." In Homo creator et receptor atrium. Ksiega pamiątkowa ks. prof. Stanisławowi Kobielusowi ofiarowana, ed. Małgorzata Wrześniak. Warszawa: Wydawnictwo Uniwersytetu Kardynała Stefana Wyszyńskiego, 2010.

EICH, Paul. "Empfängnis Mariae, unbefleckte." In Reallexikon zur Deutschen Kunstgeschichte. Vol. V. München: C.H. Beck, 1967.

FRAZIK, Józef. "Budowniczowie i artyści na usługach franciszkanów przemyskich od XVI do XVIII wieku na tle dziejów kościoła i jego wyposażenia.” Biuletyn Historii Sztuki 37 (1975).

FRAZIK, Józef. "Budowniczowie i artyści na usługach franciszkanów przemyskich od XVIII wieku.” In Sztuka Przemyśla i ziemi przemyskiej. Zbiór studiów, ed. Maria Dłutek AND Jerzy Kowalczyk. Przemyśl-Warszawa: Instytut Sztuki Polskiej Akademii Nauk, 2004. 
Galante, Gennaro A. Guida sacra della citta di Napoli. Napoli: Stamperia del Fibreno, 1872.

GuldAN, Erich. Eva und Maria. Graz-Köln: Gundolf, 1966.

HAUG, Wolfgang, John THIEDE. “Bergl Johann Baptist Wenzel.” In Allgemeines Kunstler-Lexikon. Vol. 57. München: Saur, 2008.

HoRnung, Zbigniew. "Stanisław Stroiński (1719-1802).” Prace Sekcji Historii Sztuki i Kultury Towarzystwa Naukowego we Lwowie 2 (1935).

HoRnung, Zbigniew. "Uwagi w sprawie autorstwa polichromii ściennej kościoła oo. Franciszkanów w Przemyślu." Teka Konserwatorska. Polska południowo-wschodnia. Vol. II. Rzeszów: Biuro Dokumentacji Zabytków w Rzeszowie, 1985.

IsPHORDING, Eduard. Gottfried Bernhard Goz, 1708-1774. Ein Augsburger Historienmaler des Rokoko und seine Fresken. Weissenhorn: Konrad, 1997.

IsPHORDING, Eduard. "Göz Gottfrired Bernhard.” In Allgemeines Künstler-Lexikon. Vol. 57. München: Saur, 2008.

Katalog zabytków sztuki w Polsce. Vol. 8. "Powiat krasnostawski.” Book 8, ed. Rryszard Brykowski and Ewa Rowińska. Warszawa: Instytut Sztuki PAN, 1964.

Katalog zabytków sztuki w Polsce. Vol. 8. “Woj. Lubelskie. Pow. Włodawski.” Book 18, ed. Janina Rutkowska and Ewa Smulikowska. Warszawa: Instytut Sztuki PAN, 1975.

Katalog zabytków sztuki w Polsce. Vol. 3 (new series). "Województwo rzeszowskie. Leżajsk, Sokołów Małopolski i okolice.” Book 4. Ed. Ewa Śnieżyńska-Stolotowa and Franciszek Stolot. Warszawa: Wydawnictwa Artystyczne i Filmowe, 1989.

Katalog zabytków sztuki w Polsce. Vol. 10 (new series). "Miasto Przemyśl," ed. Jakub Sito. Part 1. “Zespoły sakralne,” ed. Piotr Krasny and Jakub Sito. Warszawa: Instytut Sztuki PAN, 2004.

KruŻel Krzysztof, Jan MотYKA. Francesco Bartolozzi. Ryciny ze zbiorów graficznych Polskiej Akademii Nauk w Krakowie. Kraków: Międzynarodowe Centrum Kultury, 1995.

ŁoBESKI, Felicjan. "Opisy obrazów znajdujących się w kościołach miasta Lwowa.” Dodatek Tygodniowy do Gazety Lwowskiej 2 (1852).

Ostrowski, Jan K. “Kościół parafialny p.w. Matki Boskiej Śnieżnej.” In Kościoły i klasztory rzymskokatolickie dawnego województwa ruskiego, Materiały do dziejów sztuki sakralnej na ziemiach wschodnich dawnej Rzeczypospolitej. Kościoly i klasztory Lwowa z okresu przedrozbiorowego. Vol. XIX. Part 1, ed. Jakub Adamski [et al.]. Kraków: Międzynarodowe Centrum Kultury w Krakowie, 2011.

POKLEWSKI, Józef. "Kościół i klasztor pobernardyński w Zamartem k. Chojnic.” Teka Komisji Historii Sztuki 4 (1968) (Toruń).

SCHILLER, Gertrud. Ikonographie der christlichen Kunst. Vol. IV. Part 2. Gutersloh: Verlagshaus Gerd Mohn, 1980.

SoBIESZCZuK, Halina. "Malowidła ścienne w kościele popaulińskim we Włodawie.” Roczniki Humanistyczne 6 (1957).

StoGA, Andrzej, "Marceli Dobrzeniewski - zagadkowy malarz z Włodawy i Łęczeszyc.” BHS 34 (1972).

STOGA, Andrzej. “Quadratura w malarstwie polskim XVIII w. Malowidła na sklepieniach.” BHS 42 (1980).

StogA, Andrzej. "Malarstwo ścienne na Warmii w XVIII w. i jego oddziaływanie." In Sztuka 1. pot. XVIII wieku. Materiały sesji Stowarzyszenia Historyków Sztuki. Rzeszów [1978], Warszawa: Państwowe Wydawnictwo Naukowe, 1981. 
STOGA, Andrzej. "Iluzjonistyczne sklepienie w kościele w Klesztowie." In $W$ kręgu badań nad sztuka polska. Studia z historii sztuki $i$ kultury, ed. Karol Majewski. Lublin: Katolicki Uniwersytet Lubelski, 1983.

SzYNDLAREwICZ, Magdalena. "Gabriel Sławiński-malarz fresków i obrazów. Uwagi wstępne.” In Między Wrocławiem a Lwowem. Sztuka na Ślasku, Małopolsce i na Rusi Koronnej w czasach nowożytnych, ed. Andrzej Betlej, Katarzyna Brzezina Piotr, Oszczanowski. Wrocław: Wydawnictwo Uniwersytetu Wrocławskiego, 2011.

TOMINEC, Roman. "Immaculata in arte slovenica." In Virgo Immaculata. Acta Congresssus mariologici-mariani Romae anno 1954 celebrati. Vol. XV. Romae: Academia Mariana Internationalis, 1957.

WILDMOSER, Rudolf. Gottfried Bernhard Göz als ausfuhrender Kupferstecher: Untersuchung und Katalog der Werke. Augsburg: Augsburger Buchdruck und Verlagswesen, 1984-85.

Woeckel, Gerhard. "Göz Gottfrired Bernhard.” In Neue Deutsche Biographie. Vol. VI. Berlin: Duncker \& Humblot 1964.

\section{THE RECEPTION OF THE ENGRAVINGS OF GOTTFRIED BERNHARD GÖZ'S MARIAN SERIES IN THE MONUMENTAL PAINTING OF THE LVIV CIRCLE IN THE $18^{\mathrm{TH}}$ CENTURY}

\section{Summary}

The graphic series dedicated to the Mother of God, defined as Sub tuum praesidium confugimus, by Gottfried Bernhard Göz (1708-1774) was an inspiration for the monumental painting of the Rococo period in Poland in the times of the Saxon kings. The series of engravings with a devotional character made with the stipple engraving technique presents 12 signed Marian scenes: the Immaculate Conception of the Blessed Virgin Mary, Mary's Birth, the Presentation of Mary, Mary and Joseph's Matrimony, the Annunciation, the Visitation, the Purification, the images of Our Lady of Sorrows, and the Assumption. Other scenes are connected with Mary's patronage - as the Queen of the Rosary - and her intercession. The prints, as researchers of Göz's work assume, prove his mature style that was shaped in the years 1737-1740, when he formed a publishing "company" together with the Klauber brothers, Joseph Sebastian and Johann Baptist. He used the motifs occurring in the series many times e.g. on the vault of the nave in the Dominican nuns' St Stefan Church in Habsthal (1748; Upper Swabia), in the sketch and painting for the Cistercian monastery in Birnau (1748-1750). These motifs were also found in Bavarian Marian shrines, e.g. Frauenchiemsee, Maria Mitleid Kapelle and Mater Dolorosa Kapelle with paintings by Balthasar Furtner (1761) and in a church in Niederaschau and Kleinmariazell (1763-1765). References to the series may also be found in the area of Slovenia, i.e. on the vault of Grajska Kapela in Novo Celje (1758-1763).

The prints were known to the circle of Lviv artists active in the 18th century and they were used as models for numerous figural compositions. First of all the Lviv painter Stanisław Stroiński (1719-1802) used them for the decorations, among others, of the interior of the Franciscan Marian sanctuary in Leżajsk, in the Franciscan Holy Spirit Church in Krystynopol (1756-1759 (now Chervonohrad in Ukraine), and in the decoration of St Anne's Chapel in the Holy Trinity Benedictine Church in Przemyśl. The series of prints was also used by the painter Gabriel Sławiński in the decoration of the chancel in St Lawrence Parish Church in the village of Żółkiewka and on the vault of the post-Pauline St Louis Church in Włodawa. 
The engravings are a significant model for Polish painting because of their style, technique and original approach to the conventional religious theme.

Key words: G.B. Göz's engravings; monumental painting.

\section{Translated by Konrad Szulga}

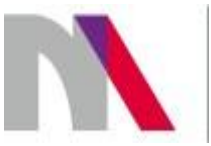

The preparation of the English version of Roczniki Humanistyczne (Annals of Arts) and its publication in electronic databases was financed under contract no. 836/P-DUN/2018 from the resources of the Minister of Science and Higher Education for the popularization of science.

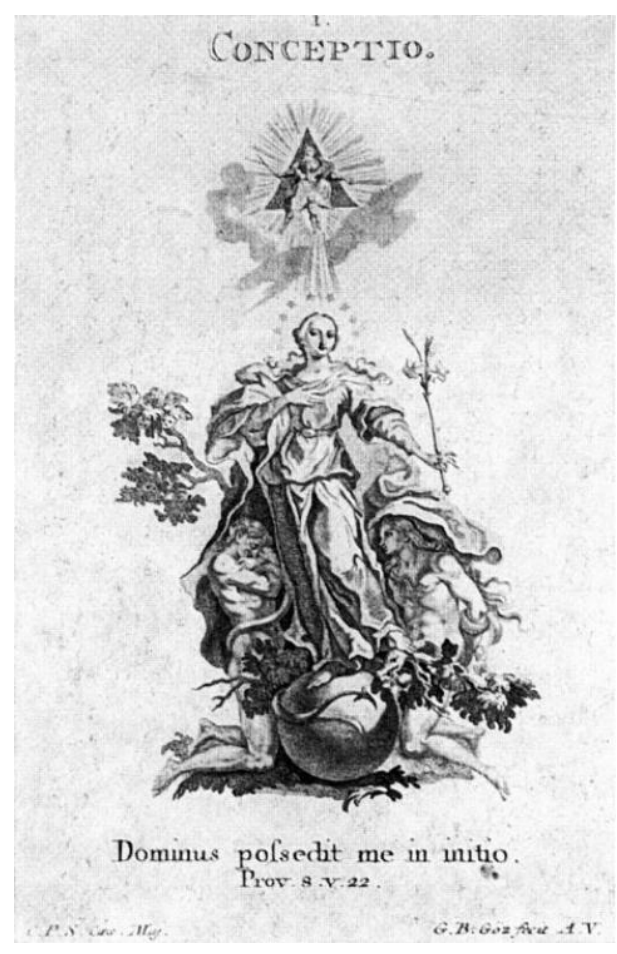

1. Conceptio, engraving from the series, Life of Mary, ca. 1750, Gottfried Bernhard Göz, reprod.: E. Guldan, Eva und Maria, Graz-Köln 1966

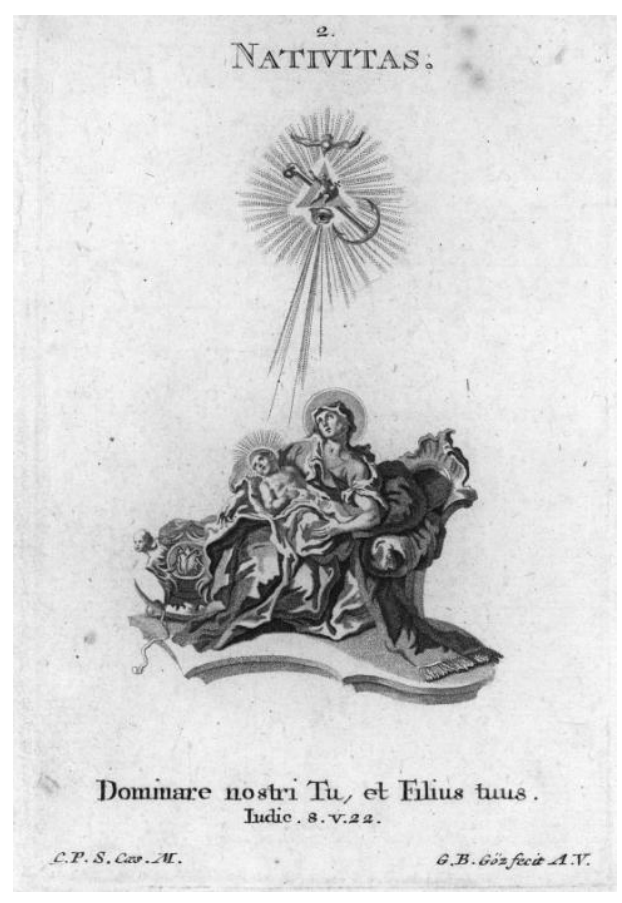

2. Nativitas, engraving from the series, Life of Mary, ca. 1750, Gottfried Bernhard Göz, reprod.:

Fotoarchiv, Grafische Sammlungen Stadt Augsburg, Kunstsammlungen und Museen, Augsburg 


\section{Pressentatio.}

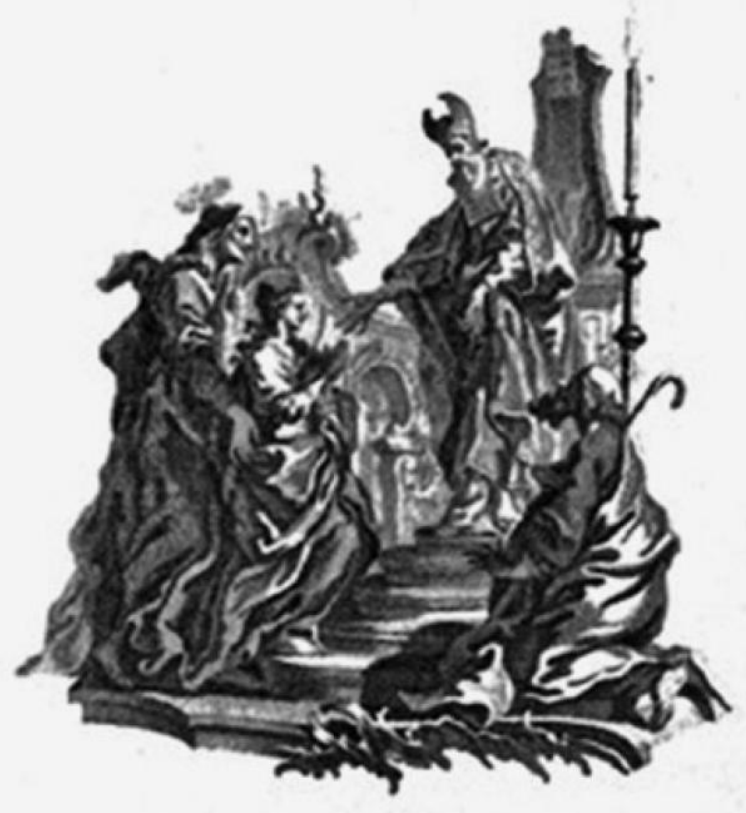

Placuit oblatio. Gen.24:vis.

c.r.s.c.zar.

e.m.oingat A.V.

3. Presentatio, engraving from the series, Life of Mary, ca. 1750, Gottfried Bernhard Göz, reprod.: Wildmoser, Gottfried Bernhard Göz..., fig. 37 


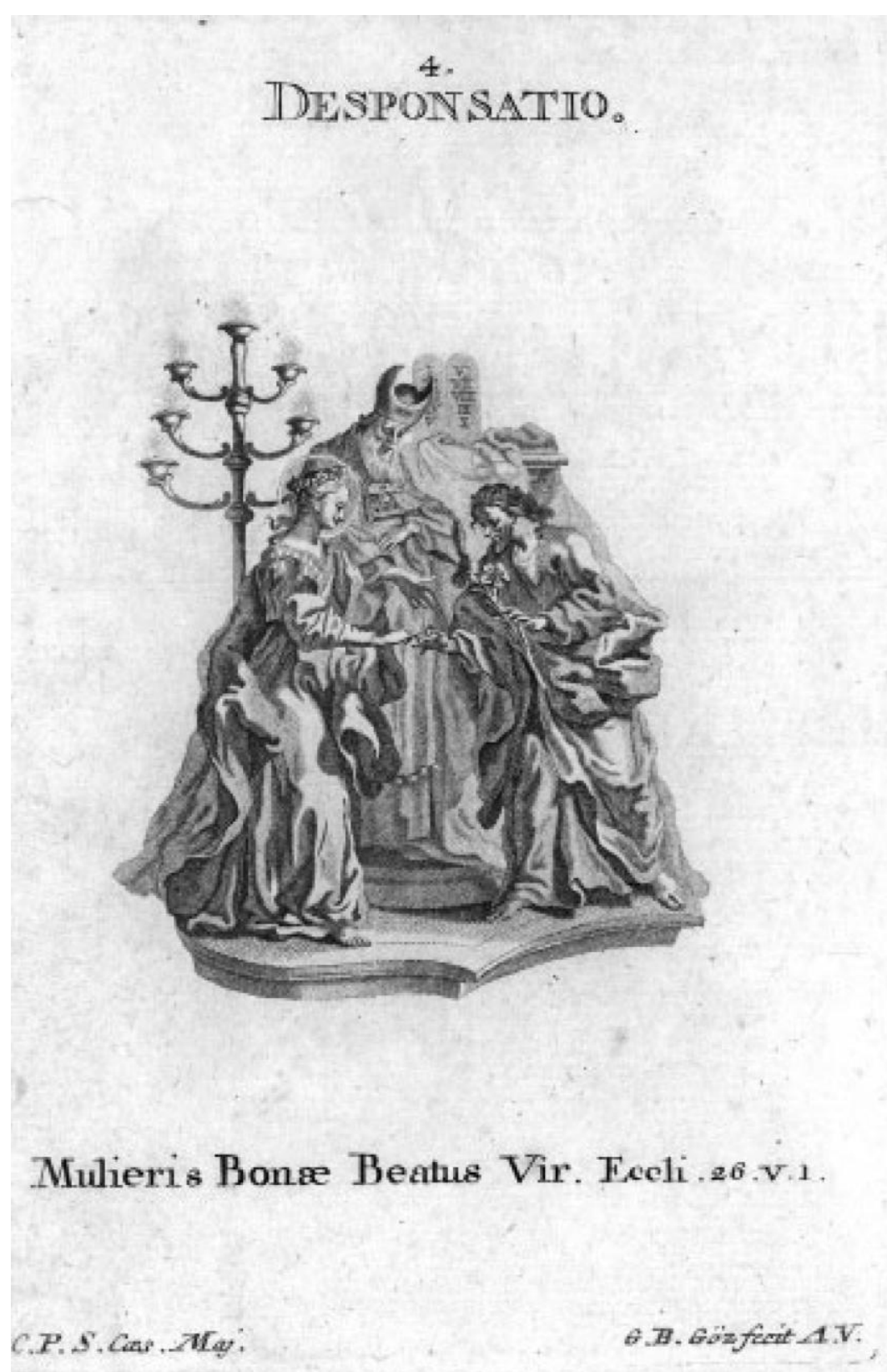

4. Patrocinium, engraving from the series, Life of Mary, ca. 1750, Gottfried Bernhard Göz, reprod.: Fotoarchiv, Grafische Sammlungen Stadt Augsburg, Kunstsammlungen und Museen, Augsburg 


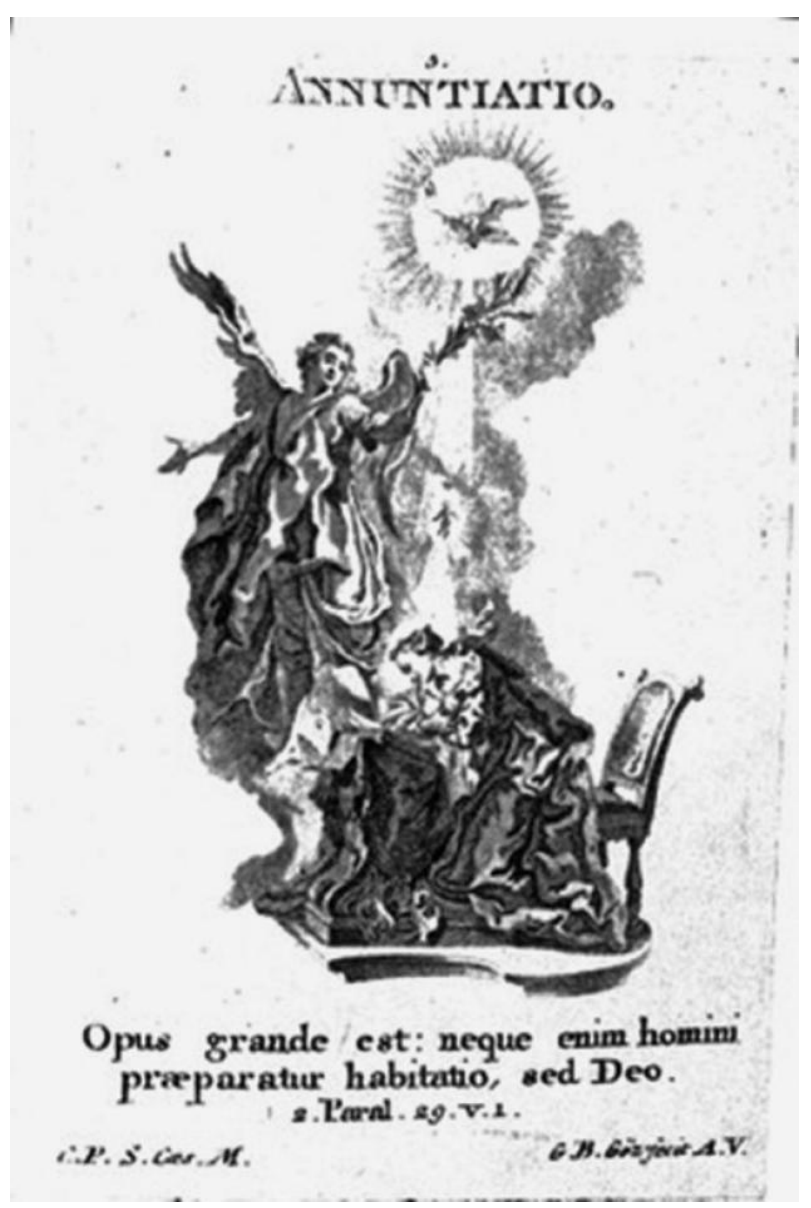

5. Annuntiatio, engraving from the series, Life of Mary, ca. 1750, Gottfried Bernhard Göz, reprod.: Fotoarchiv, Grafische Sammlungen Stadt Augsburg, Kunstsammlungen und Museen, Augsburg 


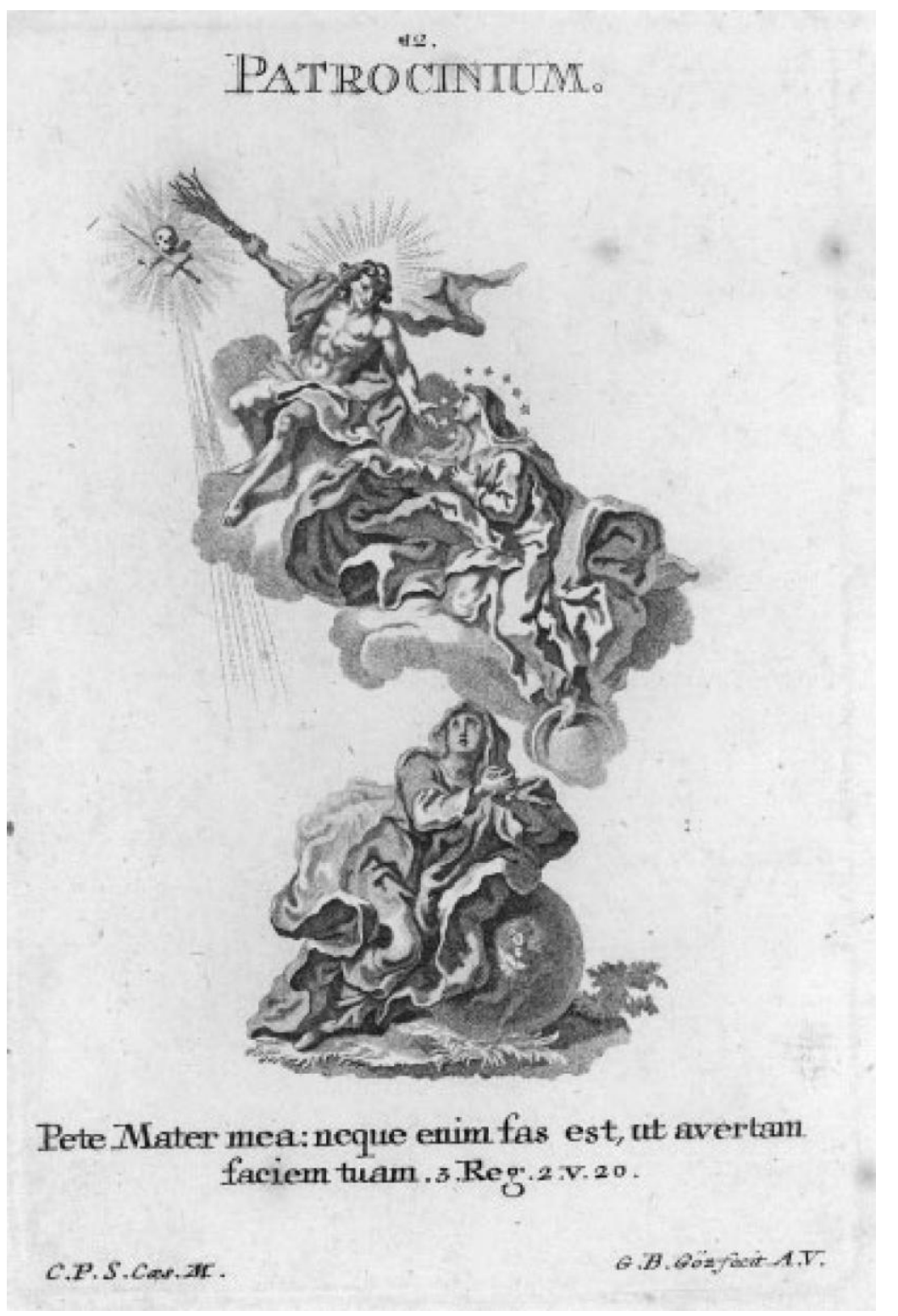

6. Patrocinium, engraving from the series, Life of Mary, ca. 1750, Gottfried Bernhard Göz, reprod.: Fotoarchiv, Grafische Sammlungen Stadt Augsburg, Kunstsammlungen und Museen, Augsburg 


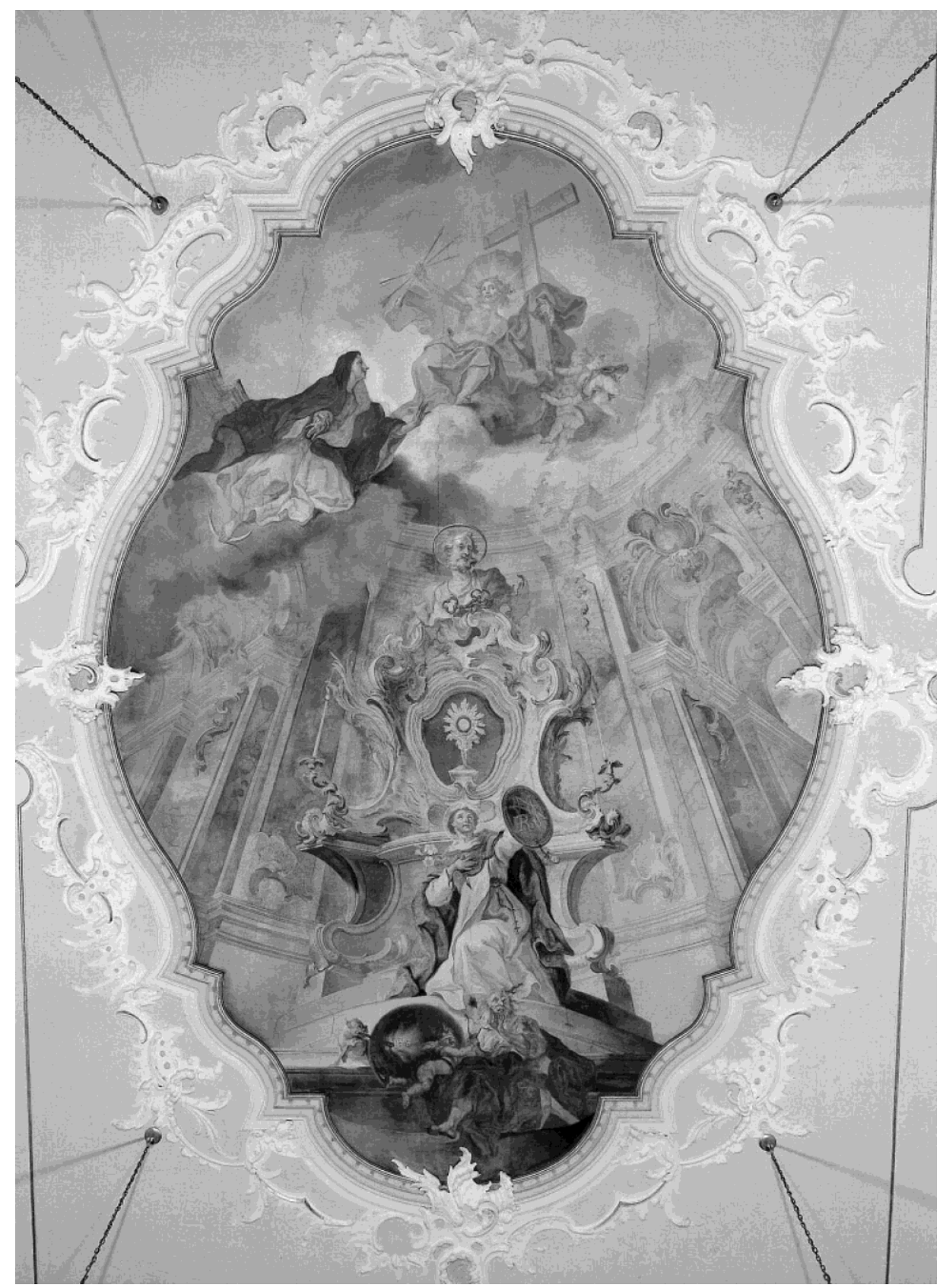

7. Intercession of St Dominic, 1748, Gottfried Bernhard Göz, painting on the vault of the aisle of St Stephen' Church of Dominican nuns in Habsthal, Germany 


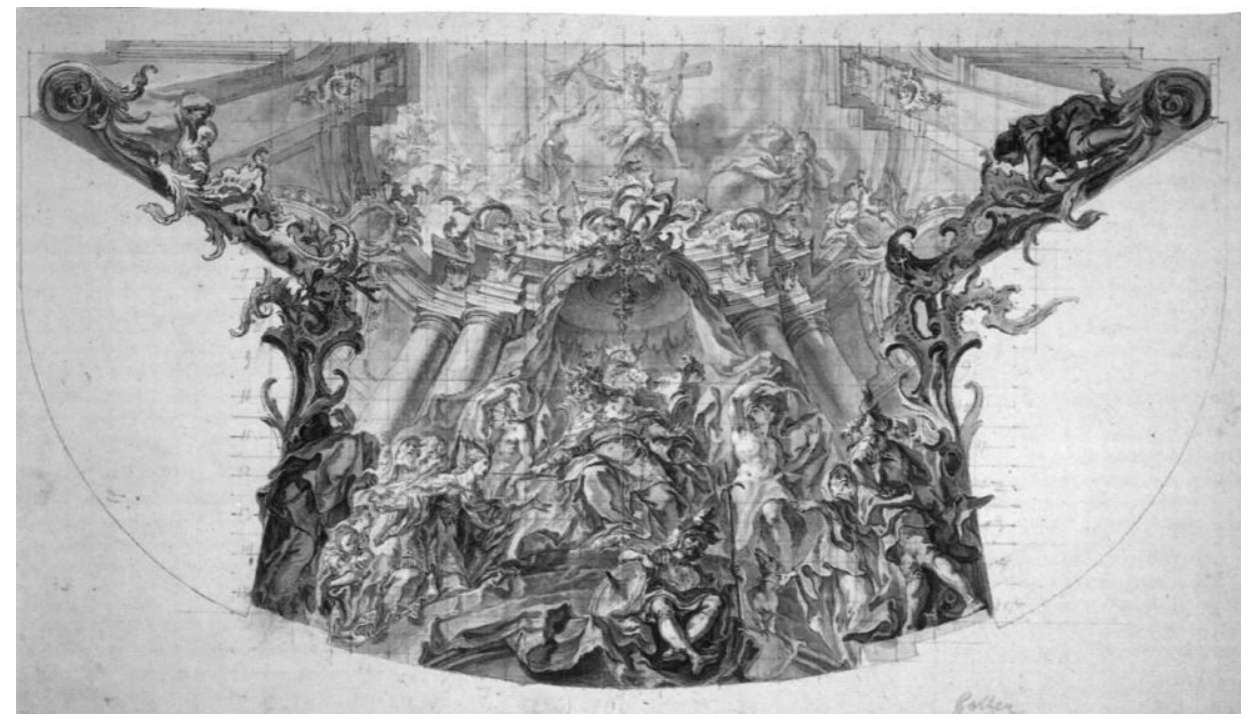

8. Intercessio Mariae, 1748-1750, Gottfried Bernhard Göz, painting on the vault of the pilgrimage church in Birnau, Germany

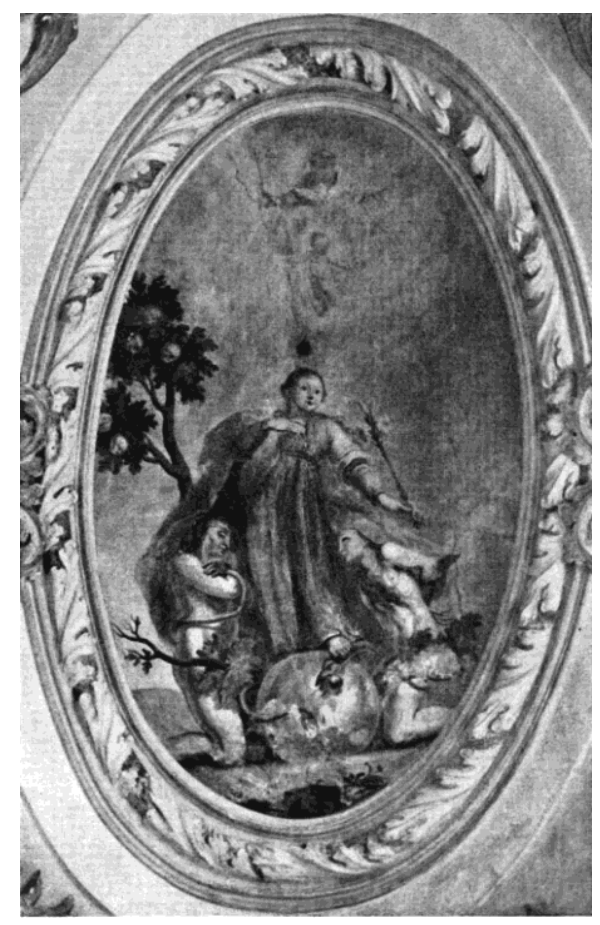

9. Mary's Matrimony, 1763-1765, Johann Baptist Wenzel Bergl, painting on the vault of Kleinmariazell Church, Austria 


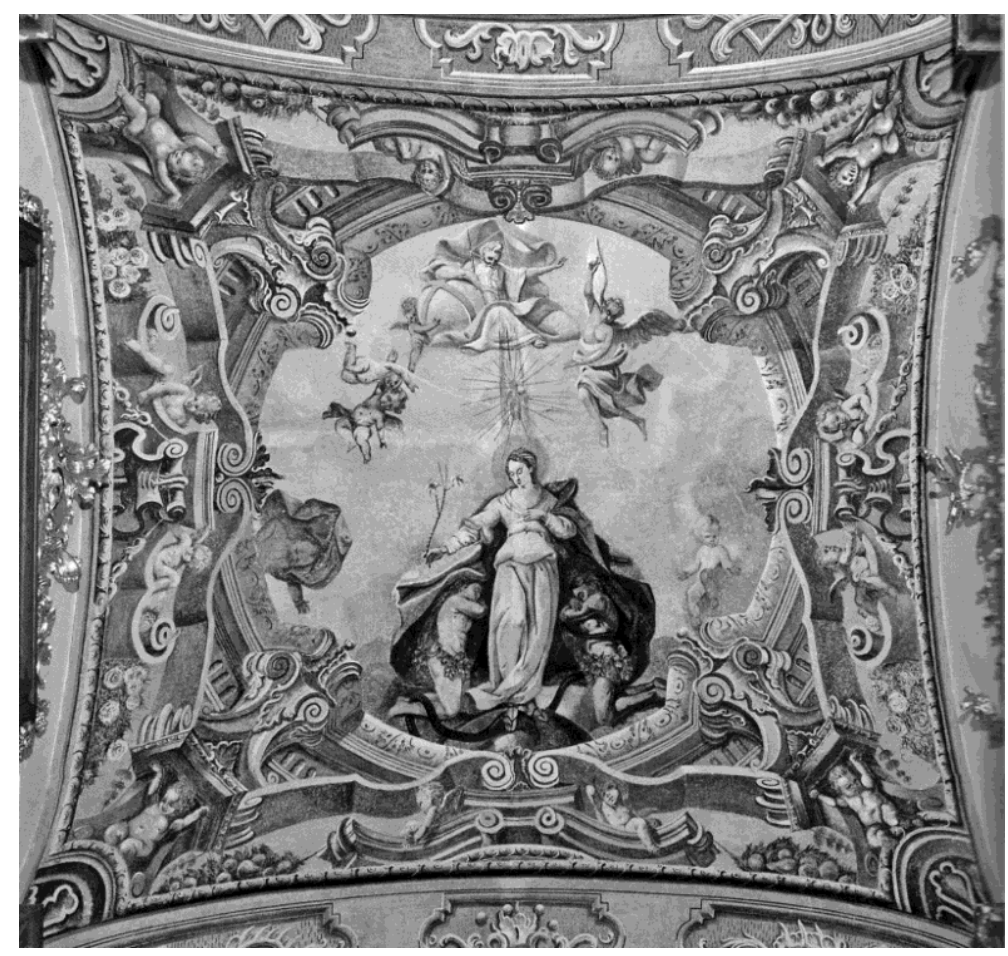

10. Immaculate Conception of the Blessed Virgin Mary, 1758-1763, Anton Jozef Lerhinger (Lerchinger), painting on the vault of Grajska Kapela in Novo Celje, Slovenia

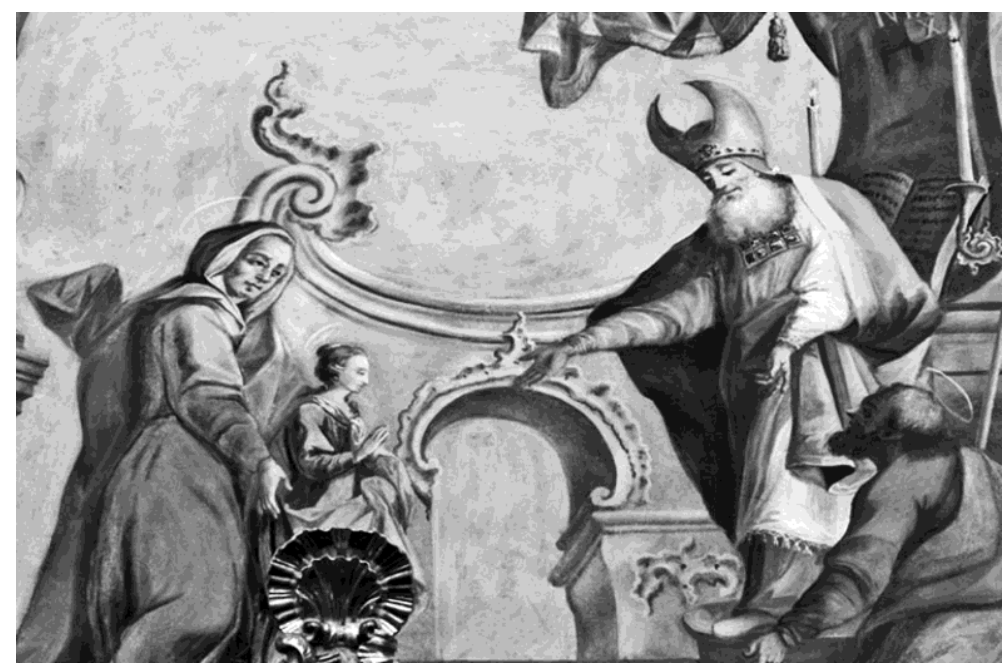

11. Mary's Introduction to the Temple (fragment), 1757, Stanisław Stroiński, wall painting in the aisle of the Bernardine church in Leżajsk, Poland 


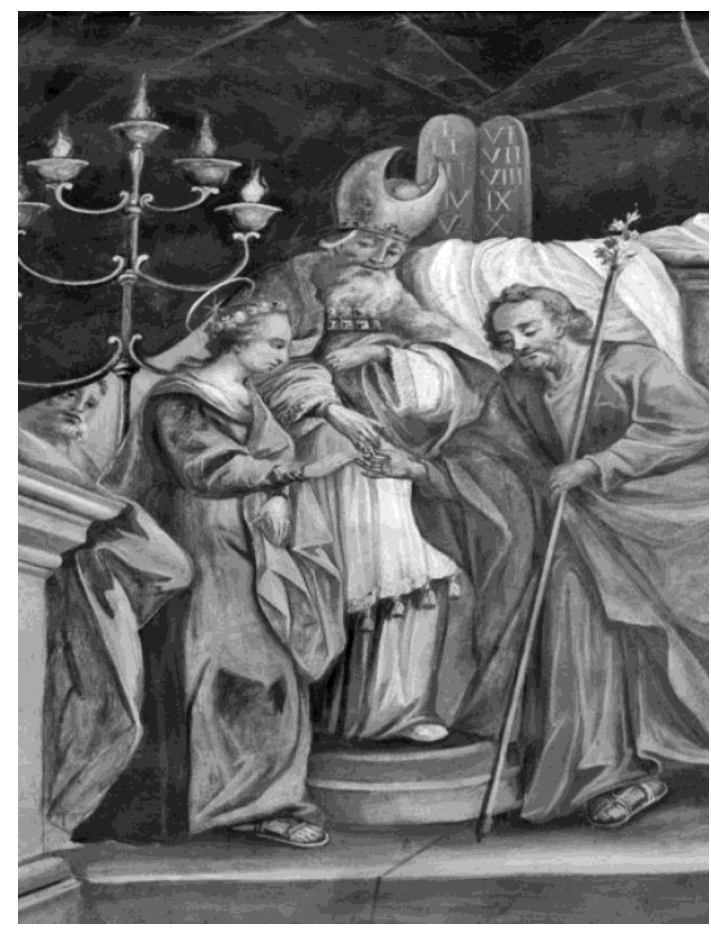

12. Mary's Matrimony (fragment), 1757, Stanisław Stroiński, wall painting in the aisle of the Bernardine church in Leżajsk, Poland

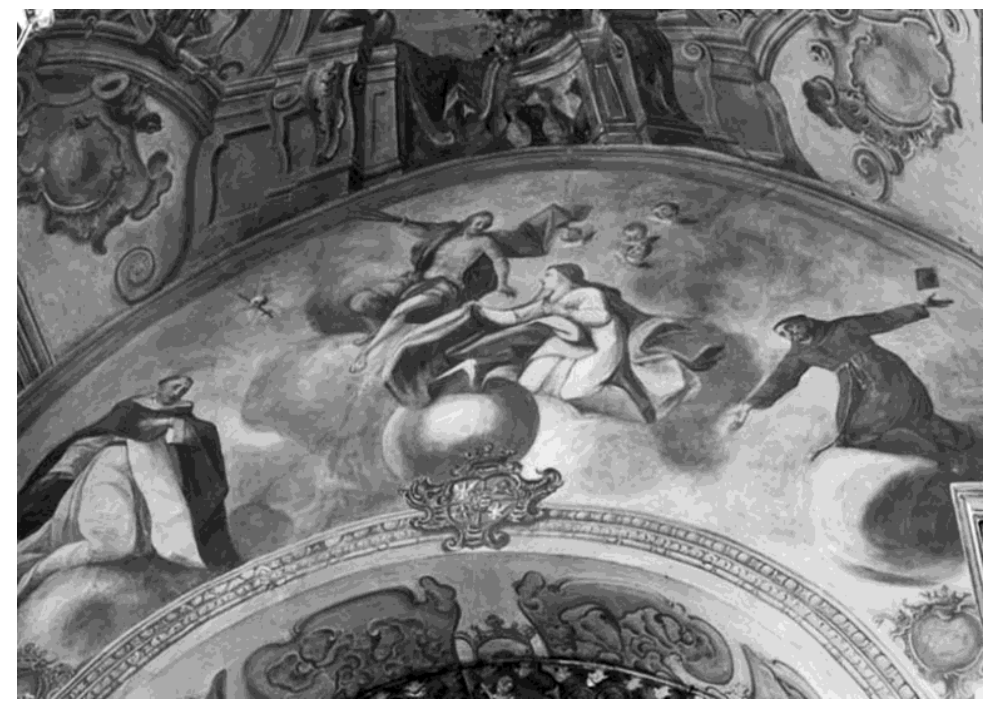

13. Intercession during Lord's Wrath, 1758, Stanisław Stroiński, painting in the nave of the Bernardine church in Leżajsk, Poland 


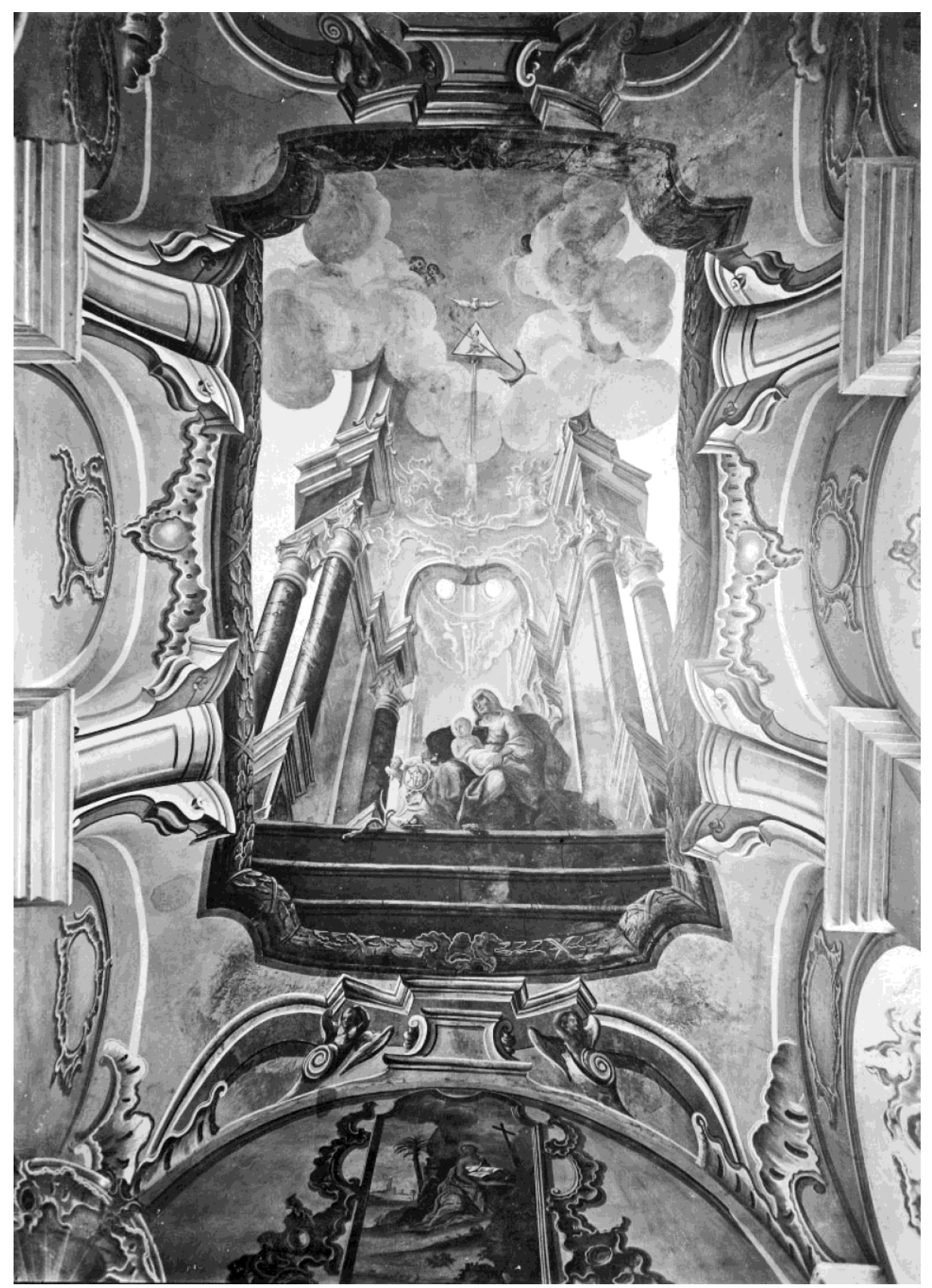

14. St Anne, 1758, Stanisław Stroiński, painting on the vault of the Bernardine church in Chervonohrad, Ukraine 


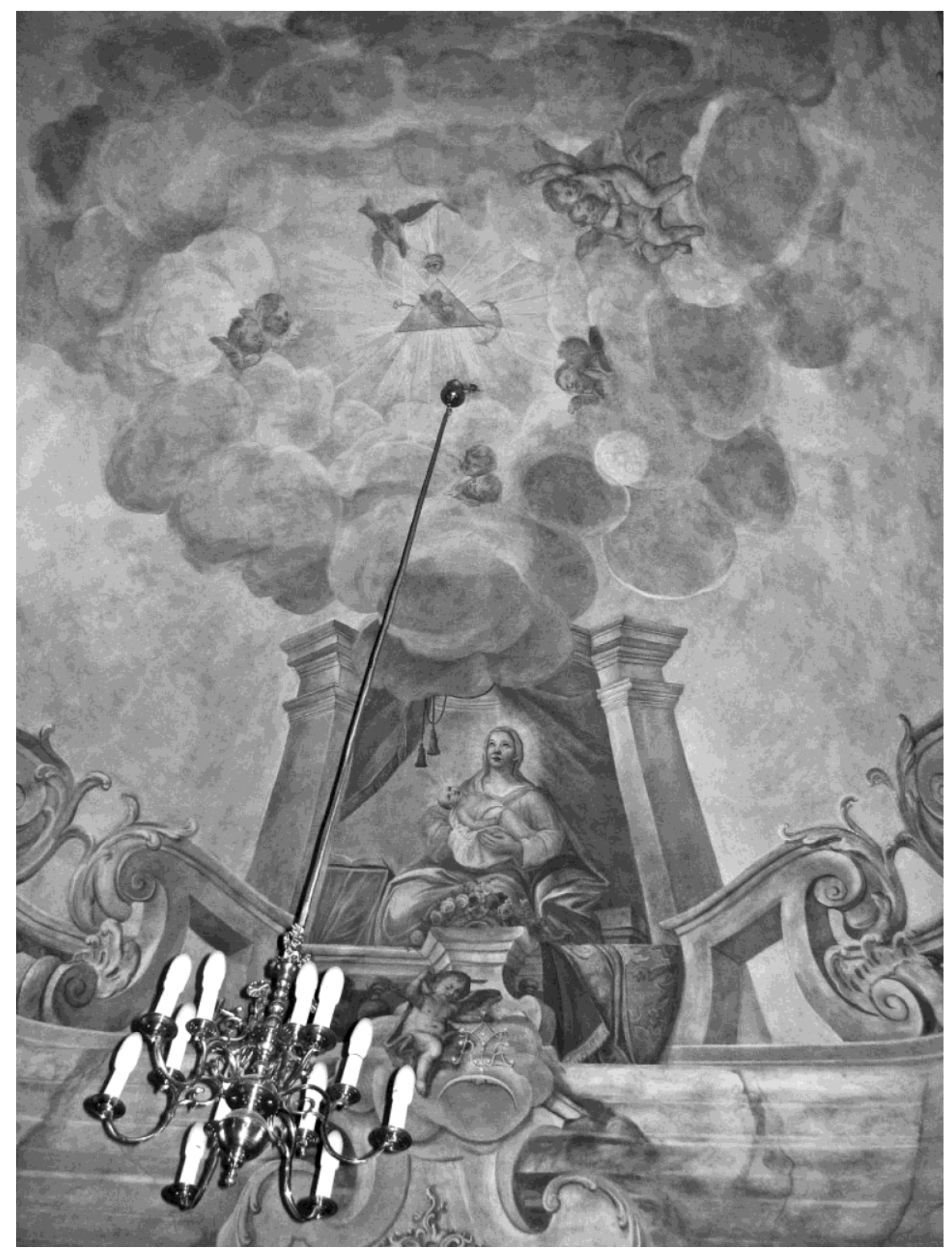

15. Adoration of the Holy Trinity by St Anne with Baby Mary, 1773-1777, Stanisław Stroiński, painting on the vault of the Chapel of St Anne of the church of Benedictine nuns in Przemyśl, Poland 


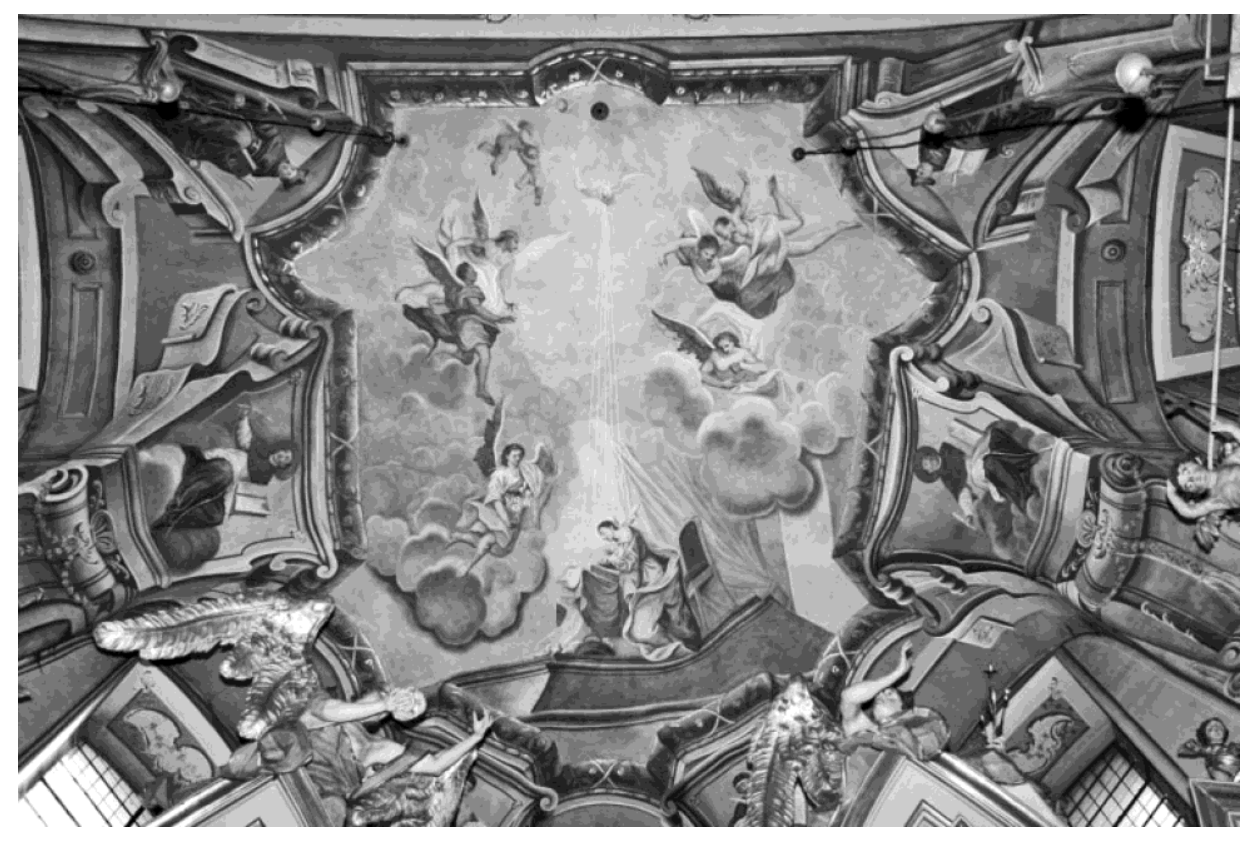

16. Annunciation of the Blessed Virgin Mary, 1771-1777, J. Rybkiewicz, painting on the vault of the chancel of the Conventual Franciscan church in Przemyśl, Poland 


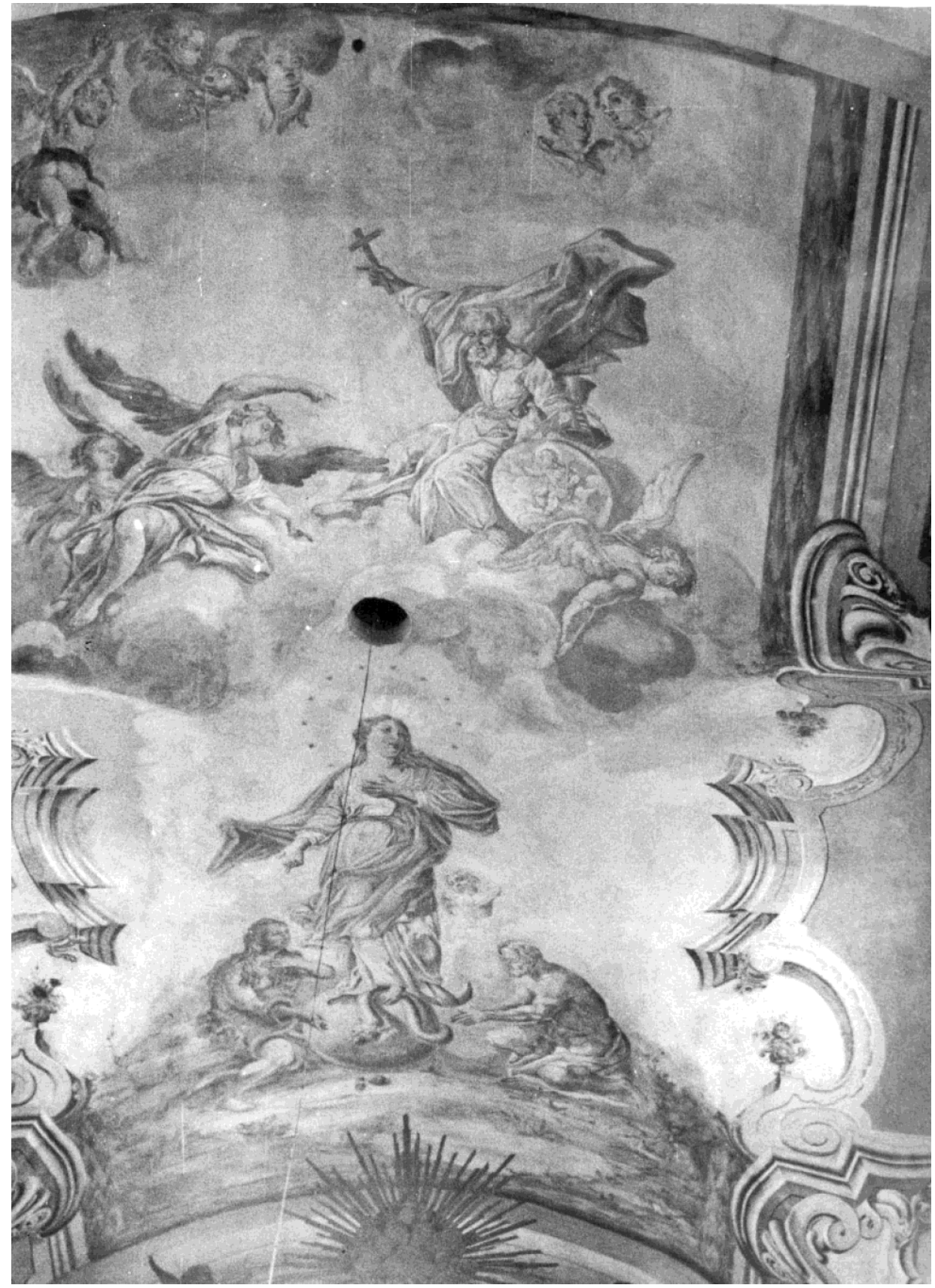

17. Immaculate Conception of the Blessed Virgin Mary, ca. 1776, Gabriel Sławiński, painting on the vault of the chancel of the parish church in Żółkiewka, Poland 


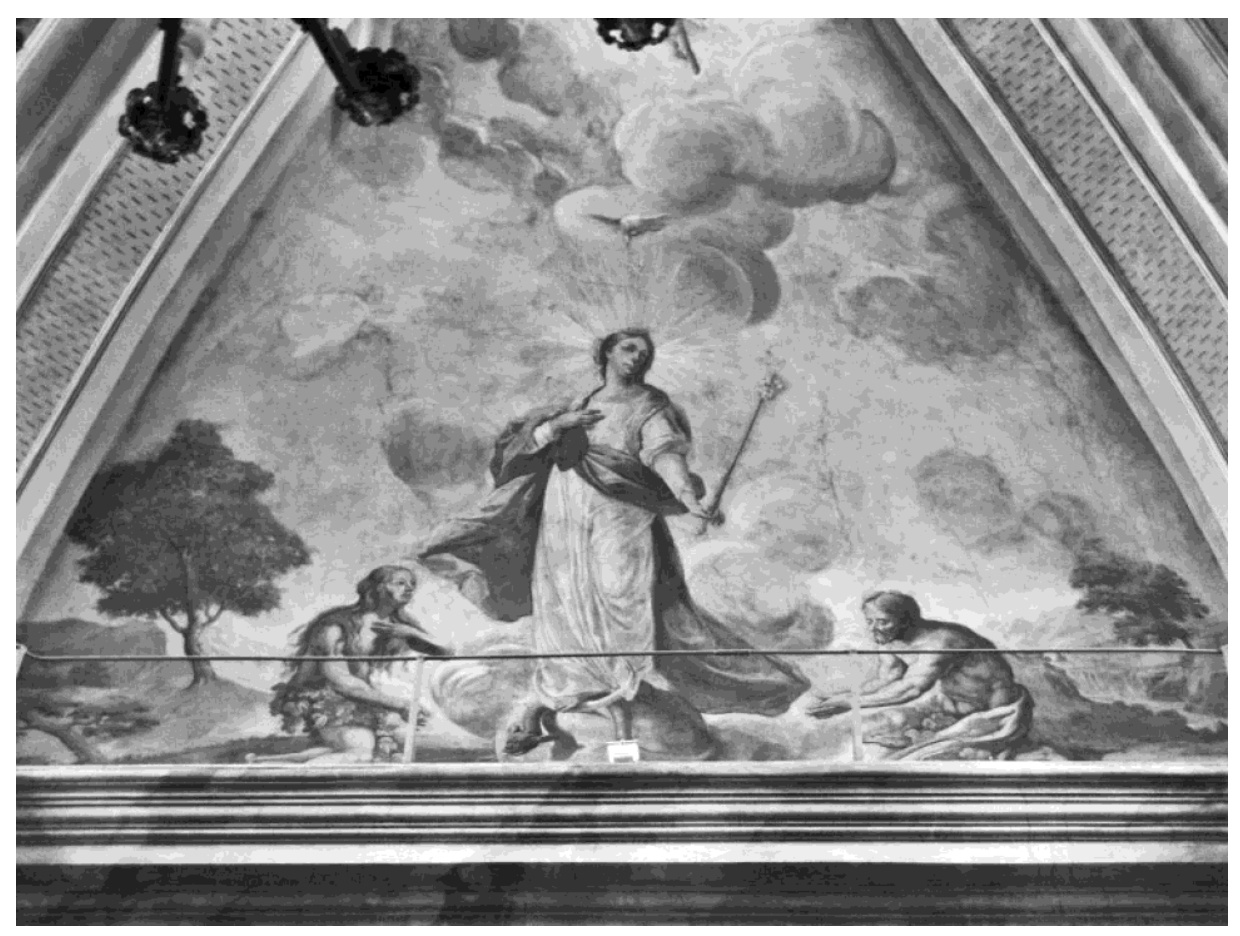

18. Immaculate Conception of the Blessed Virgin Mary, after 1784, Gabriel Sławiński, painting in the aisle of the post-Pauline church in Włodawa, Poland 